Colson. The formation of nicotine monohydrochloride liberates about twice as much heat as that of the dihydrochloride under like conditions; hence a probable difference in constitution of the two nitrogen groups of nicotine. The action of nicotine on coloured reagents shows at once a difference in the two basicities. - On the myelocytes of fishes, by M. J. Chatin. In fishes, as in other zoological groups, the nervous elements termed myelocytes, are not to be referred to a special histic type, but to the nerve cell ; which is simply modified, chiefly by enlargement of the nucleus, and corresponding reduction of the somatic part. - On the continuity of the pigmented epithelium of the retina with the external segments of the cones and rods, and the morphological value of this arrangement in vertebrates, by MM. R. Dubois and J. Renaut. This new fact makes it probable (according to the authors) that in the retina of vertebrates a similar process occurs to that in the light. sensitive apparatus of Mollusks like Pholas; by mechanism of impression and transformation of luminous movement into contractile, then sensorial. - On strabismus, by M. H. Parinaud. The immediate cause of the deviation (in squinting) is a disorder of innervation, excess in convergence, defect in divergence, caused generally by the accommodative effort in one case (hypermetropia), and the little use made of accommodation in the other (myopia). The deviation, when sufficiently fixed and prolonged, induces anatomical changes both in the brain-connections and the tissues of the eye (in the latter case, not only shortening of muscles, but retraction of all relaxed fibrous parts, especially Tenon's capsule). This has important bearings on treatment. On the morphology and the biology of the fungus Oidium albicans (Robin), by MM. G. Linossier and G. Roux. Besides the yeast form, and the globulofilamentous, he finds a third, similar to chlamydospores, and prohably needing some new natural habitat for full development. This fact, with the absence of ascospores, \&c., suggests removal of the organism from the genus Saccharomyces. Again, it is found, that in culture of the fungus, the complication of form increases with the molecular weight of the aliment; there is a growing tendency to form long thin filaments. This tendency is also favoured by high temperature, excess of oxygen, a trace of nitrates, and antiseptics.Comparative activity of various digitalines, by M. Bardet. $\mathrm{He}$ compares crystallized and amorphous digitaline, prepared according to the French codex, German digitoxine, French digitaleine, and German digitaline (the power of the two last is much less ihan those of the others).

\section{DIARY OF SOCIETIES.} LONDON.

THURSDAY, NOVEMBER $2 \mathrm{I}$

Royal Society, at 4:30-(ז) Further Discussion of the Sun-spot Observations at South Kensington ; (2) on the Cause of Variability in Condensing Swarms of Meteorites: J. Norman Lockyer, F.R.S.-On the Local Paralysis of Peripheral Ganglia, and on the Connection of Different Classes of Nerve Fibres with them : J. N. Langley, F.R.S., and W. Lee Dickinson.-On the Tubercles on the Roots of Leguminous Plants, with Special
Reference to the Pea and the Bean (Preliminary Paper): Prof. H. M. Ward, F.R.S

LinNEAN Society, at 8.--External Anatomical Characters indicating Sex in Chrysalids, and Development of the Azygos Oviduct and its Accessory Orgaus in Vanessa Io: Prof. W. Hatchett Jackson.-Anatomy of Lepidoptera: E. B. Poulton.-Lepidoptera of Ichang, North China: John $\mathrm{H}$

CHemicat

\section{S. U. Pickering. MONDAY, NOVEMBER 25}

Roval Geographical Society, at 8.30.-The Bahrein Islands, Persian

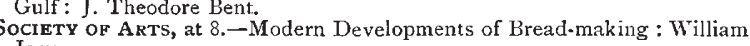
Jago.

\section{TUESDAY, NOVEMBER 26.}

Anthropological InSTITUTE, at 8.30.-The Ethnology of the Western 'Tribe of Torres Straits: Prof. A. C. Haddon.

Institution of Civil Engineers, at 8.-Water-Tube Steam-Boilers for Marine Engines: John I. Thornycroft. (Discussion.)

University College Biological Society, at 5.15.-A New Genus of Polychæt Worm: Florence Buchanan.

WEDNESDAY, November 27.

Society of ARTs, at 8.- Scientific and Technical Instruction in Elementary Schools: Dr. J. Hall Gladstone, F.R.S.

THURSDAY, NoVEMBER 27

Institution of Electrical ENGINEERS, at 8.-Electrical Engineering in America: G. L. Addenbrooke.

FRIDAY, NOVEMBER 29.

Institution of CiviL Engineers, at 7.30.-Principles of Iron Foundry Practice: G. H. Sheffield.
BOOKS, PAMPHLETS, and SERIALS RECEIVED.

Pubblicazioni del Real Osservatorio di Palermo, vol. iv. (Palermo). - Obeah Witchcraft in the West Indies: H. J. Bell (Low).- Through Atolls and Islands in the Great South Sea: F. J. Moss (Low).-The Lesser Antilles: O. T. Bulkeley (Low).-Humanitism : W. A. Macdonald (Trübner). Memoirs and Proceedings of the Manchester Literary and Phil sophical Society, vol. ii., 4th series (Manchester). - Report on the Mining Industry of New Zealand, r889 (Wellington).- Reports on Mining Machinery and I reat ment of Ores in Australıan Colonies and America (Wellington). - Die Laby rinthodonten der schwäbischen Trias: E. Fraas (Sturtgart, E. Schwelzer-
bart'sche).-The Butterfly; its History. \&c. : J. Stuttard (Unwin).-A bart'sche). -The Butterfly; its History, \&c. : J. Stuttard (Unwin).-A
Glos'ary of Biological, Anaromical, and Physi logical Terms: T. Dinman Gloseary of Biological, Anatomical, and Physi logical Terms : T. Dunman
and V. H. W. Wingrave (Griffith, Farran). -An Intr duction to the Study of Shakespeare: Dr. H. Corson (Boston, Heath). -On the $\Lambda$ nimal Alkaloids Sir W. Aitken, 2nd edition (Lewis) -Matebele Land and the Vtctoria Falls, and edition ; F. Oatec, edited by C. G. Oates (K. Paul).-Euclid's Elements of Geometry, books i. and ii.: H. M Taylor (Cambridge University Press).-Travels in India by Jean Baptiste Tavernier, 2 vols. V. Ball (Macmillan). - Results of Meteorological ("bservations made in New South Wales during I887; H. C. Russell (sydney, Potter). $\frac{1}{\text { E }}$ Ethnographische Beiträge zur Kenntniss des Karolinen Archipels : J. S. Kubary (Leiden. Trap).-Les Animaux et les Végétaux Lumıneux: H. Gadeau de Kerville (Paris, Baillière). - Bibliographie Générale de l'Astronomie, tome premi rr. 2nde partie: J. C. Houzeau and A. Lancaste
(Bruxelles, Hayez).-The Evolution of Sex, Prof. P. Geddes and J A Thomson (Scott).-Synthèse Scientifi uue et Philosophique: A H. Simonin (Paris, E. Leroux) - The State : W. Wilson (Boston, Heath). - N tes on Sport and Ornithology: late Crown Prince Rudolf if Austria; translated by C. G. Danford (Gurney and Jackson).-Blackie's Ge graphical Manuals ; No. 2, the British Empire; Part $\tau$, The Home Countries: W. G Baker (Blackie).-Gold-Fields of Victoria; Reports of the Mining Registrars for the Working of the Registration and Inspection of Mines and Mining Ma chinery Act during the Year I 888 (Melbourne). - M agnetism and Electricity chinery Act during the Year I 888 (Melbourne).-M agnetism and Electricity, Advanced and Honours Questions : A. Jamieson (Griffin).-Hlectrical Engineering, ',rdinary and Honours Questions : A. Jamieson (Griffin). - Results of Rain, River, and Evaporation Observations made in New South Wales during 1888: H. C. Russell (Sydney, Potter). - Astron mical and Meteorological Workers in New South Wales, 1778-1860: H. C. Russell (Sydney,
Potter). - The Thunderstorm of October 26, r888: H. C. Ku sell. -On a Potter).-The Thunderstorm of October 26, r888: H. C. Ku sell. -On a C. Russell at the First Meeting of the Australian Associati A. - Phe Source C. Russell at the First Meeting of the Australian Associati n. I he
of the Underground Water in the Western Districts : H. C. Russell.

\section{CONTENTS.}

PAGE

Rock Metamorphism . . . . . . . . . 49 Hand-book of Descriptive and Practical Astronomy 49 Electrical Undertakings. By J. A. F. . . . . . 50 Dianthus. By J. G. B. .......... 5 I Our Book Shelf:-

Poyser: "Magnetism and Electricity"

Barber: "The Engineer's Sketch-book."-N. J. i. . $5^{2}$

Markham: "A Life of John Davis" . . . . . . . . 53

Wood: "The Brook and its Banks," and "The Zoo". . . . . . . . . . . . . 53

Letters to the Editor:-

Protective Coloration of Eggs.-Dr. Alfred R. Wallace; Rev. Fred. F. Grensted . . . . . . . 53

Science and the India Civil Service Examinations.Henry Palin Gurney ..........

'The Physics of the Sub-oceanic Crust.-A. J JukesBrowne

The Composition of the Chemical Elements.-A. M. Stapley

Is Greenland our Arctic $\dot{\text { Ice }} \dot{\mathrm{C}}$ ?-S. E. Peal • •

Globular and other Forms of Lightning.--Reuben

"Phillips "'- Prof. George J. Romanes, F.R.S.

How not to Teach Geometry.-Herbert J. Woodall 60 A Brilliant Meteor.-Wm. Scarnell Lean . . . . 60 The Causes and Character of Haze. By Hon. F. A.

R. Russell

The Pulsion Mechanical Telephone . . . . . .

Notes . . . . . . . . . . 66

Our Astronomical Column:-

Objects for the Spectroscope.-A. Fowler . . . . . 68

The Minimum Sun-spot Period . . . . . . . . . 68

Return of Brorsen's Comet . . . . . . . . . . . 69

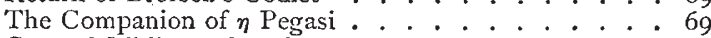

General Bibliography of Astronomy

J. C. Houzeau's "Vade Mecum" . . . . . . . . . 69

A New Comet . . . . . . . . . . . . . 69 Mirage in the South American Pampas. (Illustrated.)

By W. Larden . . . . . . . . . . . 69

Scientific Serials . . . . . . . . . 7 I Societies and Academies . . . . . . . . 7 I

Diary of Societies . . . . . . . . . . 72

Books, Pamphlets, and Serials Received . . . . 72 